\title{
Improving Talent Performances by Using Integrated Learning Development Program in Indonesia Leading Heavy Equipment Distributor
}

\author{
Ahmad Anwari \\ Master of Mechanical Engineering \\ Swiss German University \\ Tangerang City, Indonesia \\ ahmad.anwari@student.sgu.ac.id
}

Gembong Baskoro

Master of Mechanical Engineering

Swiss German University

Tangerang City, Indonesia

gembong.baskoro@sgu.ac.id

\author{
Edi Sofyan \\ Master of Mechanical Engineering \\ Swiss German University \\ Tangerang City, Indonesia \\ edi.sofyan@lecturer.sgu.ac.id
}

\author{
Sumarsono Sudarto \\ Master of Mechanical Engineering \\ Swiss German University \\ Tangerang City, Indonesia \\ sumarsono@mercubuana.ac.id
}

\begin{abstract}
The purpose of this research is to improve talent performance through an integrated development program to nurture and increase company competitiveness. Research is carried out by identifying problems and analyzing the factors that affect talent performance and then designing a system to fix the existing problems. From the analysis of existing data, we find that improving talent performance requires a comprehensive approach. From this research we can also conclude that an integrated learning system is very effective in increasing competence and talent performance. The combination of formal and informal learning, theory and practice provides an effective learning system
\end{abstract}

Keywords - talent, integrated development, performance management, competency development, talent map.

\section{INTRODUCTION}

The World Bank has published "The Human Capital Index 2020 Update: The Human Capital in the Time of COVID-19". In the report, Indonesia has been ranked at the 96th position (Figure.1) among 174 countries in the Human Capital Index (HCI) 2020. In the other hand, Indonesia's ranking in the Global Talent Competitiveness Index (GTCI) published by INSEAD (Institut Européen d'Administration des Affaires) increased from position 86 in 2014 to 65 in 2020. GTCI is an annual comprehensive report that can be used as an indicator to measure how a developing country and city provides human resources to increase competitiveness.

Towards 100 years of Indonesian independence, the President of Indonesia asked the Ministry of National Development Planning/Bappenas to formulate the Indonesian Vision 2045. The entire Vision of Indonesia 2045 is directed at the realization of an advanced Indonesia and one of the 5 world economic powers with superior human quality and mastery of science and technology, much better, more equitable people's welfare, and national resilience and strong and authoritative governance.

Talent is a person's ability which includes fundamental strengths, skills, knowledge, experience, intelligence, decision making, attitudes, character, encouragement, and the ability to learn and develop [1].

Formulating policies or strategies to increase talent competitiveness is not easy, it requires complex and simultaneous efforts and processes to create synergy between divisions or departments.

Since being popularized by a McKinsey consultant in 1998 through an article entitled "War of Talents", the term talent in the world of work has become increasingly popular. Talent is believed to be one of the keys to achieving organizational goals. Finding good talent management is a key strategy to keep success and competitive of the organization.

\section{A. Research Question}

- What is Talent?

- Why is talent important?

- How to identify talent?

- How to Fitting talent management into the organization (concern to equality and diversity policies)?

\section{LITERATURE REVIEW}

\section{A. Definition of Talent}

Talent is a person's ability which includes fundamental strengths, skills, knowledge, experience, intelligence, decision making, attitudes, character, encouragement, and the ability to learn and develop [1]. Talent is defined as the 
knowledge, experience, skills, and behavior that are inherent in a person and shown in daily performance [2].

\section{B. Talent Management}

Talent management is an effort to understand how a person's talents are in line with the overall efforts and functions of HR to improve company or organizational performance. Talent management objectives are as follows [3]:

- Developing the best team of excellence in competitive business conditions.

- Acquiring replacement candidates for key executive positions

- Allows for mutual replenishment between executives from various functional, geographic, and business backgrounds

- Develop the necessary career opportunities

- Build a culture that encourages the best executives to perform at their peak potential.

- Ensure that there are opportunities for the most talented employees to increase rapidly from lower levels of the company to the top levels.

- Promote diversity of executives (based on gender, ethnic background and age) in key positions, reflecting the characteristics of a broad customer and talent pool.

- Establish a potential employee assessment process whose results exceed the employee manager's perspective.

- Building a sense of belonging is the need for talented employees, opening up unlimited opportunities for special employees, and developing employees for the benefit of the company.

\section{Talent Management Model}

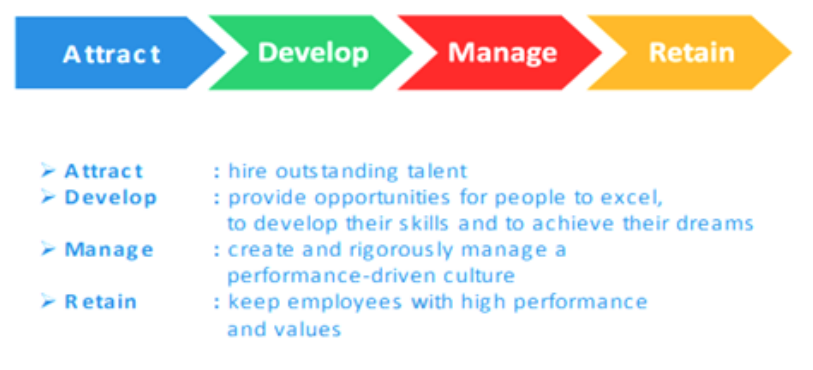

Fig. 1. Talent management model

\section{RESEARCH METHODS}

Referring to Fig. 3, this research was conducted by analyzing the performance and competency data of the last three years and analyzing the development program, from planning, execution and evaluation.

From this analysis, a number of problems were taken which became pareto. From this problem, it is determined the research objective to be achieved. After that, a literature study was conducted to obtain appropriate references and approaches theoretically based on the chosen method. The next step is to design a system (policy, procedure, method, program) that is considered effective in achieving the specified goals. From the designed system, all data are collected and analyzed to obtain results and conclusions.

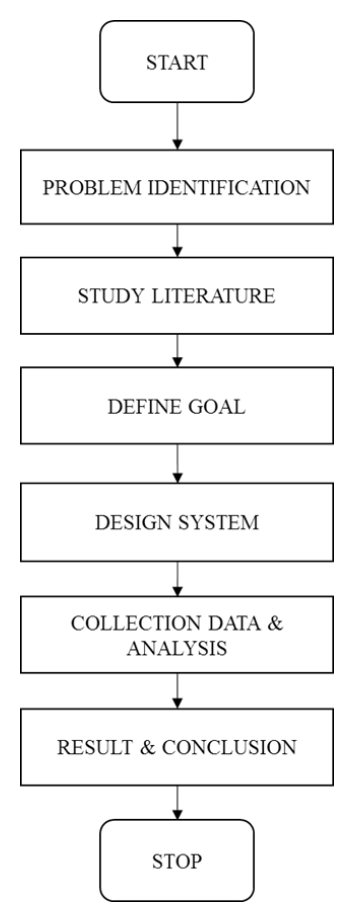

Fig. 2. Research method flowchart

\section{A. Scope of Study}

The study for this research is limited to the following:

1. Employees: generalist group employees with a minimum work period of 3 years with staff positions or above.

2. System: only focus on performance management, competency management and program development.

\section{B. Individual Development Plan}

Individual Development Plan (IDP) is a system for managing employee competency development. In this IDP, the employee development process is managed, from the planning, review and appraisal. Development planning is made in detail for each competency group, namely Behavior Competency (BC), Business Management Competency (BMC), Technical Operation Competency (TOC) and English Literacy (EL). The selection of competencies in the IDP is carried out based on the guidelines in the directory competency book and discussions with direct superiors.

\section{Talent Mapping}

Company CoX in mapping their talents uses a Human Asset Value (HAV) map which is composed of a combination of 8 behavior competencies (X axis) and performance ( $\mathrm{Y}$ axis) which produces 16 quadrants of the HAV map. 
All employee will be assessed on a scale of 1-5 for 8 Behavior Competencies, then multiplied by the weight of each, then we will get a total value of behavior competencies (in percentage) as shown in Fig. 3.

For Generalist

$$
\begin{aligned}
& \text { 1. Vision \& Business Sense } \\
& \text { 2. Customer Focus } \\
& \text { 3. Interpersonal Skill } \\
& \text { 4. Analysis \& Judgment } \\
& \text { 5. Planning \& Driving Action } \\
& \text { 6. Leading \& Motivating } \\
& \text { 7. Teamwork } \\
& \text { 8. Drive, Courage \& Integrity }
\end{aligned}
$$

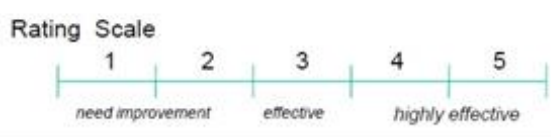

Fig. 3. Behavior competencies weight and scale

The Y-axis in the HAV diagram represents the performance value of the employees, which calculated from the last 3 (three) years. Performance values are calculated at the end of each year using normal distribution rules

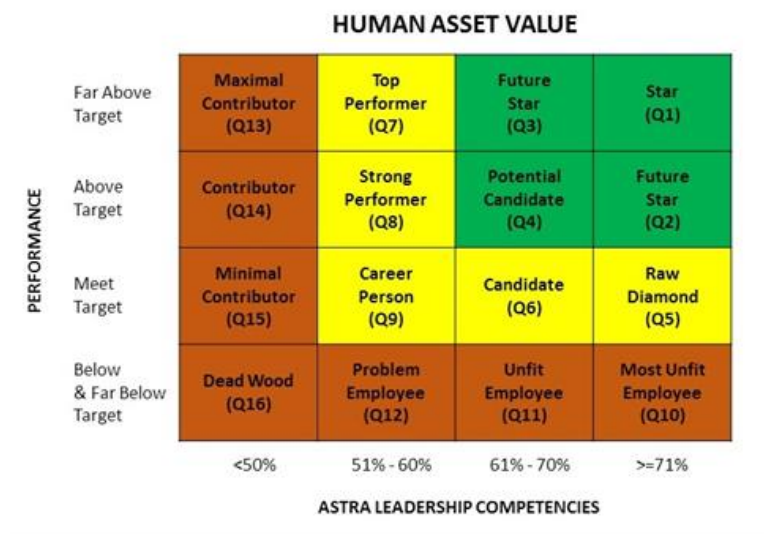

Fig. 4. Human aset value

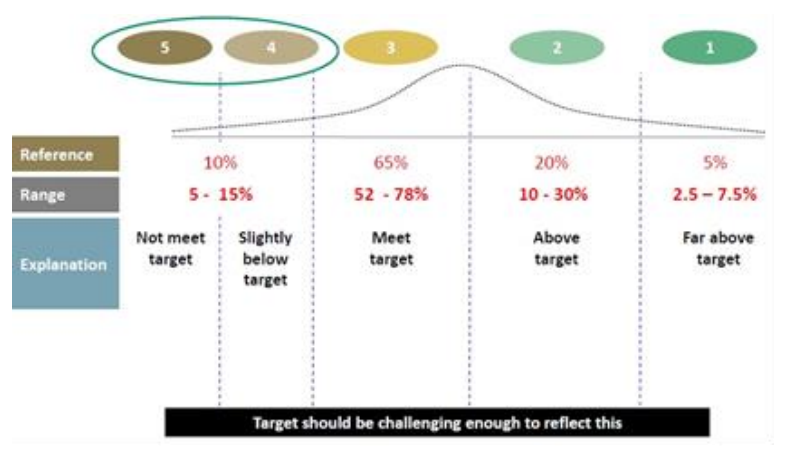

Fig. 5. Normal distribution curve
Referring to Fig. 4, from these two axes we get 16 quadrants (Q1-Q16) where of the 16 quadrants are divided into 3 groups:

a) Top Talent: Q1 - Q4

b) Potential Talent: Q5 - Q9

c) Further Development: Q10 - Q16

The focus of attention to maintain and even increase the number of talents is the "Top Talent" group (Q1-Q4) and the "Potential Talent" group (Q5-Q9). For "Top Talent" group, the focus is to creating programs to ensure performance and competency do not decrease. As for the "Potential Talent" group, the focus is on trying to develop so that people in the group increase their performance or competence so they can move to the "Top Talent" group as shown in Fig. 5.

\section{Integrated Development}

From a survey conducted by McCall, Lombardo and Eichinger, it was concluded that an effective learning process is a combination of a formal learning process (courses or book reading), social learning or learning from others and experiences from doing a job. Fig.6 is showing, the 10:20:70 learning framework emerged, which in essence is an integrated learning concept, combining formal and informal learning, theory and practice.

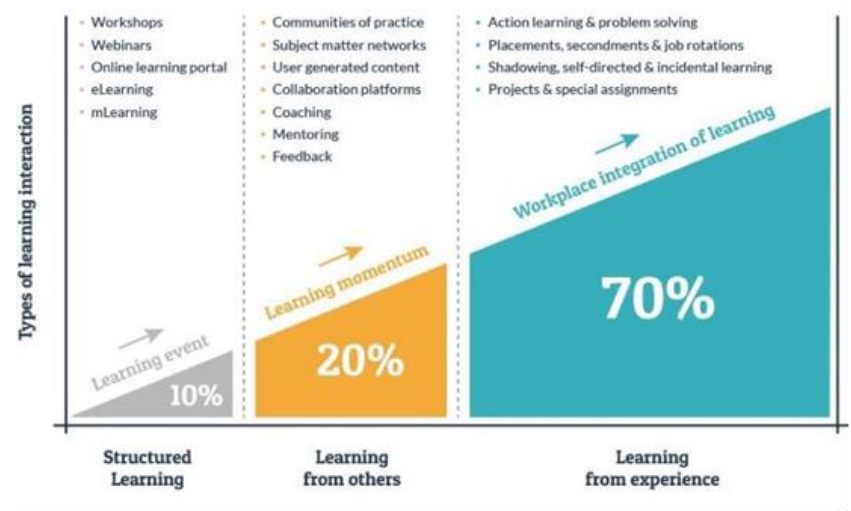

Fig. 6. 10:20:70 Integrated learning framework

\section{RESULTS AND DISCUSSIONS}

\section{A. Competency Directory Update}

The competency directory as a reference in the development and assessment process is carried out in a hierarchical adjustment process and updated in content. Hierarchically, adjustments are made in the explanation of the level of competence and explanation of indicators to better describe the 10-20-70 learning method. Meanwhile, in terms of content, updates are made to ensure the contents are always up to date.

The competency directory consists of four competency groups, namely:

1. Behavior Competency 
2. Business Management Competency

3. Technical Operation Competency

4. English Literacy

\section{B. 10:20:70 Integrated Development Result}

Formal training uses self-learning, online learning and in-class training methods where each employee receives formal training in accordance with the Individual Development Plan (IDP) that was filled in at the beginning of the year as shown in Table 1.

Social Learning (phase 20) plays an important role in the competency development process. Fig. 7 shows examples of social learning activities are mentoring, coaching or sharing. Several mentoring forums were created to facilitate leaders and experts to share experiences, tips and tricks and best practices.

TABLE I

SUMMARY REPORT OF ONLINE FORMAL LEARNING

\begin{tabular}{|c|c|c|c|}
\hline NO & NAME & ACH & $\begin{array}{c}\text { A VERAGE } \\
\text { SCORE }\end{array}$ \\
\hline 1 & EMPLOYEE 1 & $1075 \%$ & 95.3 \\
\hline 2 & EMPLOYEE 2 & $825 \%$ & 96.1 \\
\hline 3 & EMPLOYEE 3 & $683 \%$ & 100.0 \\
\hline 4 & EMPLOYEE 4 & $600 \%$ & 94.9 \\
\hline 5 & EMPLOYEE 5 & $533 \%$ & 96.9 \\
\hline 7 & EMPLOYEE 6 & $533 \%$ & 95.8 \\
\hline 8 & EMPLOYEE 7 & $450 \%$ & 93.3 \\
\hline 9 & EMPLOYEE 8 & $350 \%$ & 87.4 \\
\hline 10 & EMPLOYEE 10 & $333 \%$ & 98.0 \\
\hline
\end{tabular}

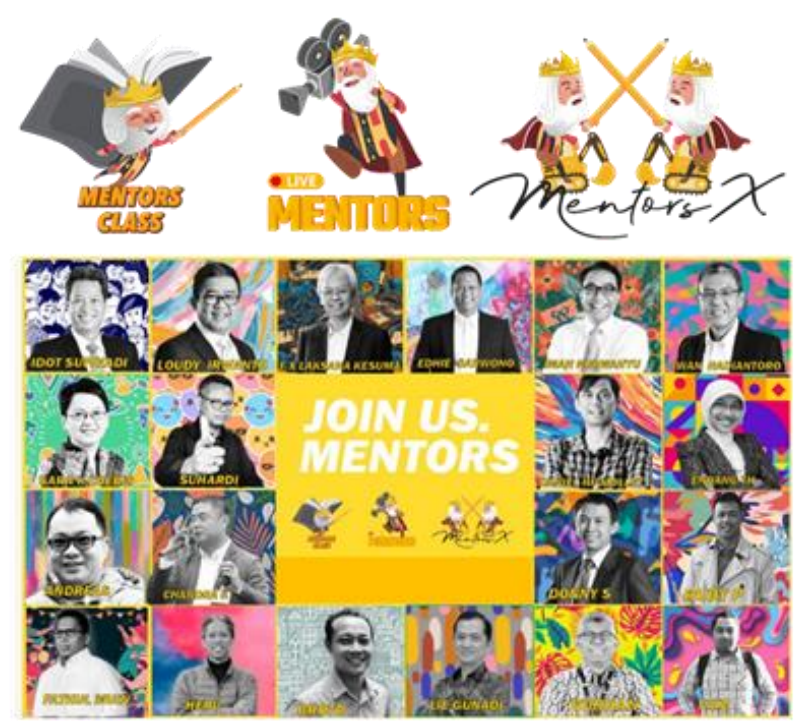

Fig. 7. Mentoring program pamflet

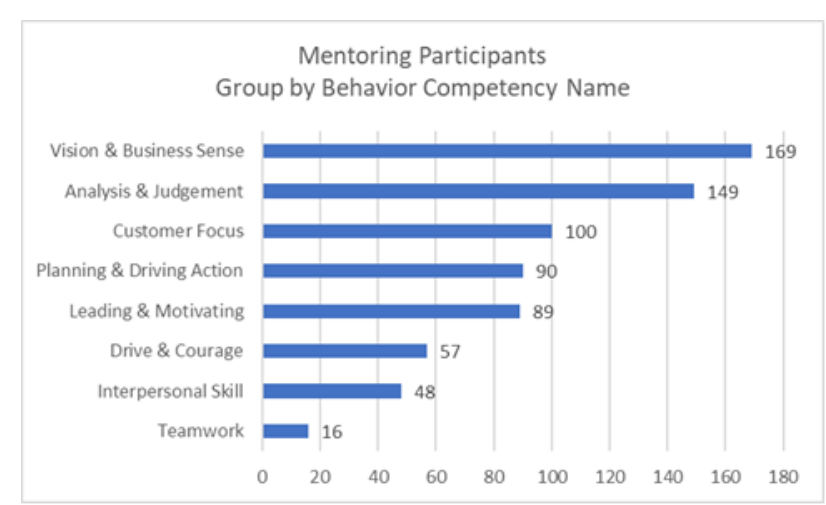

Fig. 8. Mentoring participant by competency name

Experiential Learning (phase 70) plays a very significant role in the competency development process. The opportunity to get a job assignment, project implementation or project innovation is the most effective way to learn. Therefore, every employee is encouraged to have a project that will be carried out as a part of competency development.

Every year, the company holds an innovation competition event for all employees in various categories of innovation. Along with this event, most of the employees made innovation projects as a medium to build their competence.

The innovation competition event synergizes with the development program, especially the 70 phases (experiential learning) where employees gain knowledge and skills through the experience of the project being carried out. Fig. 9 shows the enthusiasm of generalist employees in participating in innovation competitions in various categories, both as Team Leaders and Team Members.

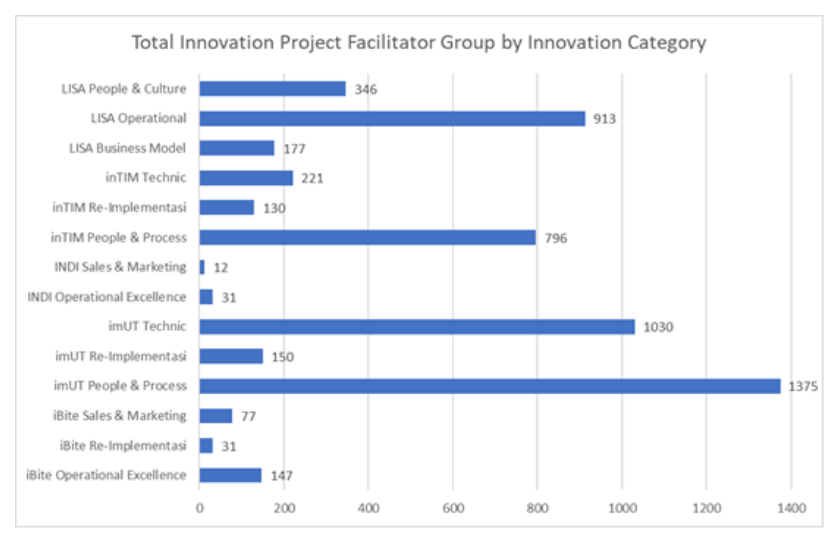

Fig. 9. Total Innovation projects by category

\section{Talent Map}

To identify and map the quality of employees based on soft skills and performance, a talent map was created in the form of a 2-dimensional axis of performance vs behavior 
competency which was divided into 16 quadrants, as shown in Fig. 10.

Employees who are included in the mapping are those with a minimum staff position and a minimum work period of 3 years. Total employees are 725 .

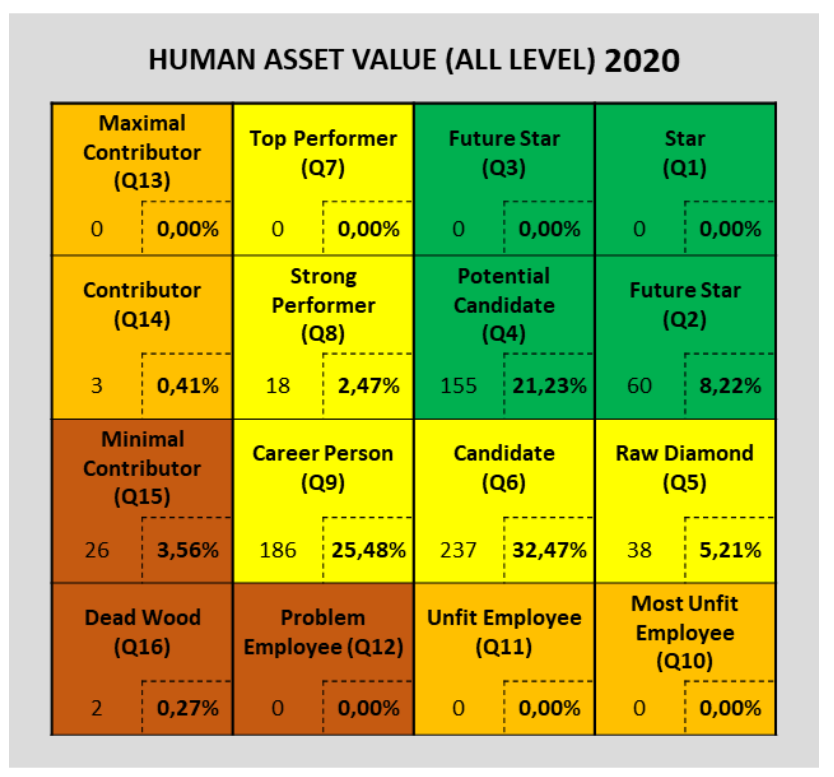

Fig. 10. Human asset value map 2020

If we compare the talent data for 2019, the total top talent (Q1-Q4) at all levels has increased quite significantly from the previous 125 or equivalent to $16.94 \%$ in 2019 , to 215 or equivalent to $29.65 \%$ in 2020 (Table 2).

This increase confirms the success of the development program which is integrated between formal learning, social learning and experential learning.

TABLE II

TALENT COMPARISON 2019 VS 2020

\begin{tabular}{|c|c|c|c|c|c|}
\multirow{2}{*}{ Criteria } & \multicolumn{2}{|c|}{2019} & \multicolumn{2}{c|}{$\mathbf{2 0 2 0}$} & \multirow{2}{*}{$\Delta$} \\
\cline { 2 - 5 } & Total & $\mathbf{\%}$ & Total & $\%$ & \\
\hline $\begin{array}{c}\text { Top Talent } \\
(\mathrm{Q} 1-\mathrm{Q} 4)\end{array}$ & 125 & $16,94 \%$ & 215 & $29,65 \%$ & 90 \\
\hline $\begin{array}{c}\text { Potential Talent } \\
(\mathrm{Q} 5-\text { Q9) }\end{array}$ & 556 & $75,34 \%$ & 479 & $66,06 \%$ & -77 \\
\hline $\begin{array}{c}\text { Further Dev } \\
(\mathrm{Q} 10-\mathrm{Q} 16)\end{array}$ & 57 & $7,72 \%$ & 31 & $4,27 \%$ & -26 \\
\hline Total & $\mathbf{7 3 8}$ & $\mathbf{1 0 0 \%}$ & $\mathbf{7 2 5}$ & $\mathbf{1 0 0 \%}$ & -13 \\
\hline
\end{tabular}

This is also confirmed by the reduction in the number of employees in the Potential Talent (Q5-Q9) group from the previous 556 or $75.34 \%$ in 2019 to 479 or equivalent to
$66.06 \%$ in 2020 . This reduction is due to performance and or the competency of a number of employees has increased so that their position on the talent map has moved from the Potential Talent group to the Top Talent group.

In general, in the last 7 years, the highest number of top talents before 2020 was achieved in 2018 where the percentage of top talent was $18.7 \%$. Meanwhile, the smallest percentage was achieved in 2015 where the percentage of talent was $13.5 \%$.

Thus, the percentage of top talent in 2020 of $29.7 \%$ is a significant jump in the last seven years (Fig. 11). This confirms that a comprehensive approach to talent development is positively correlated with increasing top talent performance

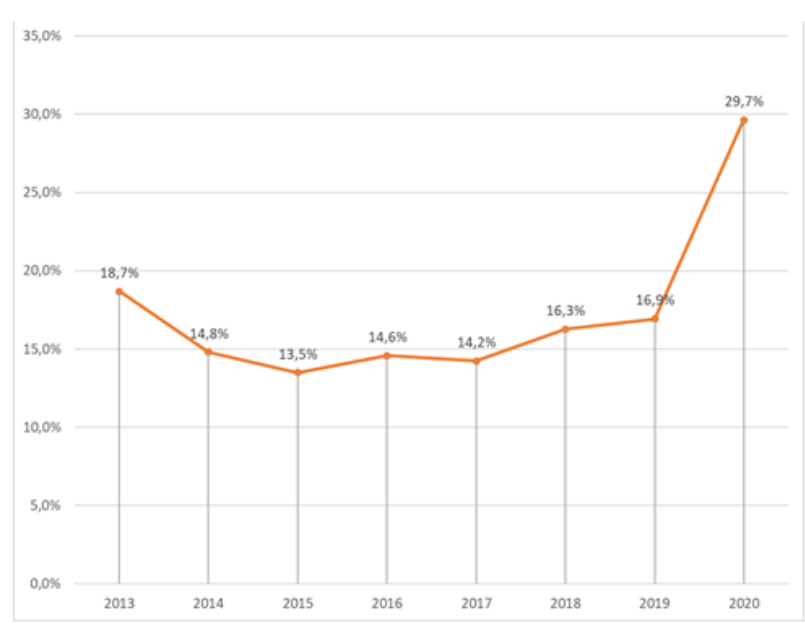

Fig. 11. Top talent percentage 2013 - 2020

\section{CONCLUSIONS AND RECOMMENDATIONS}

\section{A. Conclusions}

1) People are the key success factor in business to gain competitive advantage in this disruptive era and Talent Management is the key to achieve organizational goals

2) Competency development programs need to be designed and executed comprehensively to obtain optimal results

3) Talent assessment and mapping will help companies identify their top performers and to prepare cadre

4) Talent development programs are very important because talents are employees who can convert competencies into performance on the job quickly. Increasing the competence of talents will have a major direct impact on improving their performance and the performance of the company as a whole

5) Integrated development programs have been shown to significantly increase talent performance :

a) Top talent has increased from 125 people in 2019 to 215 people or an increase of $72 \%$ in 2020 . 
b) The ratio of Top Talent to employees has also increased to $29 \%$ or the highest in the last seven years.

c) Number of innovations has also increased from 7001 in 2019 to 8339 or an increase of $19 \%$ in 2020 .

\section{B. Recommendations}

1) The definition of "talent" to be used and implemented must be define clearly (exclusive, inclusive or combine?)

2) Measuring tools to determine the value of performance and competence need to be continuously evaluated and improved so that the assessment process and talent mapping can be carried out objectively and in a standardized manner.

3) The monitoring and reporting system for development activities needs to be continuously improved, in term of speed, accuracy and quality

\section{ACKNOWLEDGMENT}

Thank you God that I finished this research, and special thanks to Dr Edi Sofyan who is always give good direction, inspiration, introduce new tools and also challenge to freely explore various concept and knowledge. Also special thanks to Dr Sumarsono who always inspires to think systematically and introduce "slide model" to write the ideas quickly. A big thank you to PT United Tractors Tbk which has become an interesting place to grow and become a professional life school.

\section{REFERENCES}

[1] Michaels et al., The War for Talent. Harvard Business School Press: Boston, 2001.

[2] P. Cheese et al., The Talent Powered Organization: Strategies for Globalization, Talent Management and High Performance, 2008.

[3] J. Smilansky, Developing Executive Talent: Metode Efektif Untuk Mengidentifikasi dan Mengembangkan Pemimpin dalam Perusahaan. PPM Manajemen: Jakarta, 2008.

[4] M. Buckingham and R. M. Vosburgh, The 21st Century Human Resources Function: It's the Talent, Stupid! Human Resource Planning, 2001.

[5] J.A. Canon and R. Mcgee, Talent Management and Succesion Planning. The Chartered Institute of Personel and Development: London, 2007.

[6] P. Cappelli, Talent on Demand: Managing Talent in an Age of Uncertainty. Harvard Business Press: Boston, 2008.

[7] J. R. Hinrichs, High-talent personnel: Managing a Critical Resource, American Management Association: Vermont, 1966.

[8] R. Silzer and A. H. Church, "The pearls and perils of identifying potential," Industrial and Organizational Psychology, 2009.

[9] D.A. Pella and A. Inayati, Talent Management. Gramedia Pustaka: Jakarta, 2011.

[10] H. S. Yahya, Tinjauan Terhadap Sistem dan Praktek Implementasi Pengembangan Eksekutif Bertalenta - Studi Kasus pada Jenjang Direktur PT X. Jakarta: Digilib UI, 2009. 